\title{
UFO in the heart: revealed during balloon mitral valvuloplasty for severe mitral stenosis
}

\author{
Ajit Pal Singh, Anshu Kabra, Vivek Singla, Thagachagere Ramegowda Raghu
}

Department of Cardiology, Sri Jayadeva Institute of Cardiovascular Sciences and Research, Bengaluru, Karnataka, India

\section{Correspondence to} Dr Vivek Singla, drviveksingla98@gmail.com

\section{DESCRIPTION}

A 39-year-old man presented with worsening dyspnoea on exertion of 1-year duration. Cardiac auscultation revealed a loud first heart sound with a soft, rumbling mid-diastolic murmur. ECG showed $\mathrm{P}$ mitrale with tall $\mathrm{R}$ wave in V1. Chest roentgenogram revealed cardiomegaly with straightening of the left heart border suggestive of left atrial (LA) appendage enlargement, dilation of the right and left pulmonary arteries (horizontal arrows) and prominence of the both upper lobe pulmonary veins. A hyperdense lesion was noted in the left border of the cardiac silhouette (vertical arrow; figure 1). Transthoracic echocardiogram done showed severe mitral stenosis with a valve area of $0.8 \mathrm{~cm}^{2}$. No mass/thrombus could be delineated on transesophageal echocardiogram. During the percutaneous balloon mitral valvuloplasty procedure, a free floating calcified mass was seen inside the cardiac silhouette (figure 2, video 1). Possibilities considered were LA appendage mass/thrombus, healed vegetation, mitral annulus calcification and pericardial calcification. A 64 slice multidetector CT carried out showed a $1.7 \times 1.3 \mathrm{~cm}$ calcified lesion along the pericardium of the left ventricle (figure 3A-C). Cardiac CT is an extremely useful

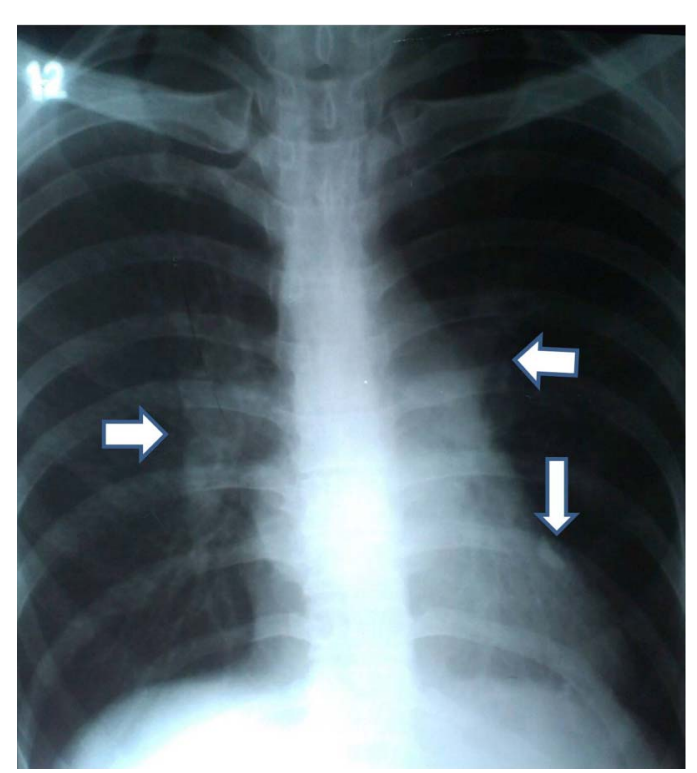

Figure 1 Chest roentgenogram showing cardiomegaly, straightening of left heart border, dilated pulmonary arteries and a small hyperdense mass in the left silhouette.

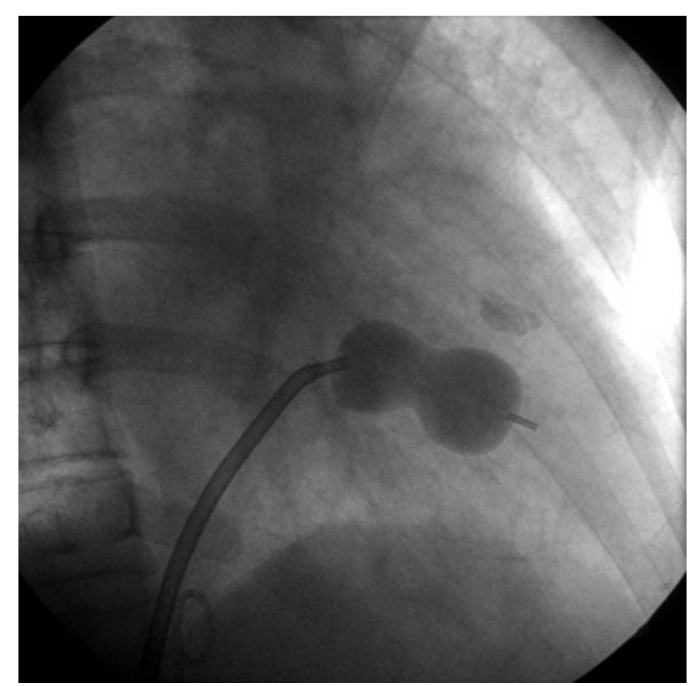

Figure 2 A calcified mass (the 'UFO') seen during balloon mitral valvuloplasty.

modality for delineation of pericardial calcification. ${ }^{1}{ }^{2}$ Various causes of pericardial calcification include inflammatory diseases, such as Tuberculosis, prior pericarditis, radiation, uraemia, hemopericardium, connective tissue disorders and rheumatic fever. Pericarditis related to previous attacks of rheumatic fever was attributed as the possible cause of the calcification in this case.

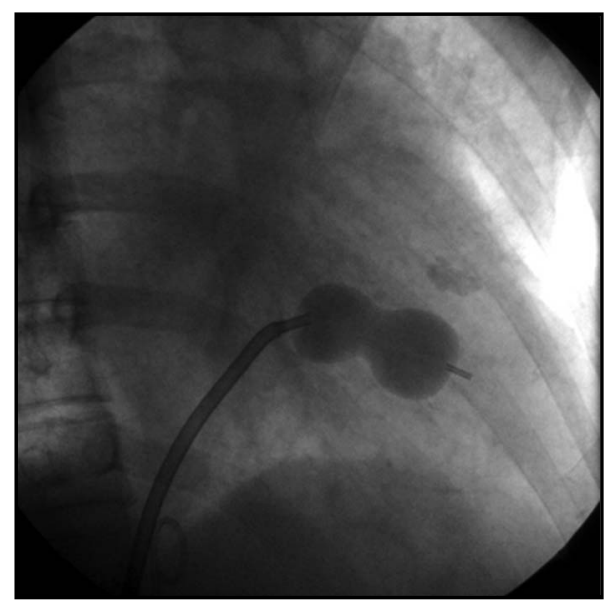

Video 1 Cine film showing mobile calcified mass during balloon dilatation of the mitral valve. 


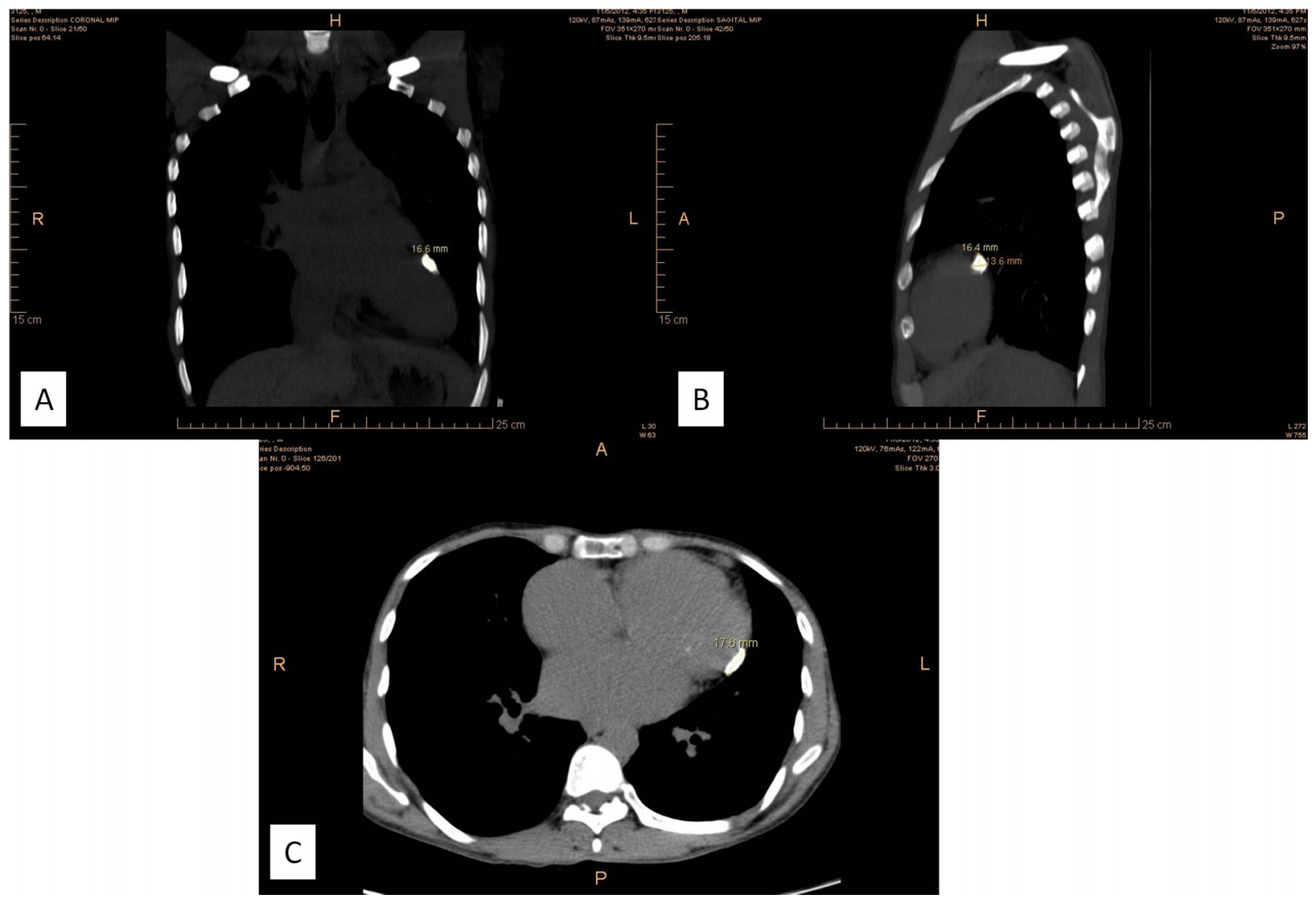

Figure 3 (A-C) Coronal, sagittal and axial multidetector CT scan sections demonstrating the location of the calcified mass in the pericardium.

\section{Learning points}

- Chest roentgenogram or fluoroscopy may not delineate the nature/location of pericardial mass.

- Pericardial calcification can occur as a benign entity as a response to previous inflammation.

- Aetiology of pericardial calcification includes inflammatory diseases such as tuberculosis, carditis, radiation, uraemia, hemopericardium, connective tissue disorders and rheumatic fever.
Competing interests None.

Patient consent Obtained.

Provenance and peer review Not commissioned; externally peer reviewed.

\section{REFERENCES}

1 Kibar Yared MD, Aaron L, Baggish MD, et al. Multimodality imaging of pericardial diseases. JACCCardiovasc Imag 2010;3:650-60.

2 Isner JM, Carter BL, Bankoff MS, et al. Computed tomography in the diagnosis of pericardial heart disease. Ann Intern Med 1982;97:473-9.

Copyright 2013 BMJ Publishing Group. All rights reserved. For permission to reuse any of this content visit http://group.bmj.com/group/rights-licensing/permissions.

BMJ Case Report Fellows may re-use this article for personal use and teaching without any further permission.

Become a Fellow of BMJ Case Reports today and you can:

- Submit as many cases as you like

- Enjoy fast sympathetic peer review and rapid publication of accepted articles

- Access all the published articles

- Re-use any of the published material for personal use and teaching without further permission

For information on Institutional Fellowships contact consortiasales@bmjgroup.com

Visit casereports.bmj.com for more articles like this and to become a Fellow 